\title{
Role of plasmids in virulence-associated attributes and in O-antigen expression in Shigella dysenteriae type 1 strains
}

\author{
K. HAIDER, A. K. AZAD, F. QADRI, S. NAHAR and I. CIZNAR
}

International Centre for Diarrhoeal Disease Research, Bangladesh (ICDDR, B), GPO Box 128, Dhaka 1000, Bangladesh

\begin{abstract}
Summary. The association of plasmids with virulence characters and O-antigen expression was studied in two virulent and seven avirulent mutant strains of Shigella dysenteriae type 1. Deletion of a 12-Mda segment from a 140-Mda plasmid in two smooth avirulent mutants made the derivatives avirulent in the Sereny test and noninvasive in HeLa cells. The mutants were unable to bind Congo red, and did not express the virulence marker antigen. Mutants completely lacking the 140-Mda plasmid also showed similar avirulent characters. However, rough mutants retained the ability to bind Congo red. Our results indicate that the essential gene(s) for virulence may be located on the 140-Mda plasmid, a small deletion from which may lead to avirulence. This deletion did not affect the protein antigen expression nor change their antigenicity. Analysis of lipopolysaccharide (LPS) patterns showed that strains containing the 6-Mda plasmid produced the complete LPS and were smooth, whereas strains containing either the 140- or a 4- or 2-Mda plasmid, in the absence of the 6-Mda plasmid, produced smaller amounts of $\mathrm{O}$ antigen and were rough. Westernblot analysis and crossed immuno-electrophoresis gave similar results. The 140-, 4-, or 2-Mda plasmid, in the absence of the 6-Mda plasmid, may code for non-specific galactosyl transferase-like activity which can add, non-specifically and at a reduced level, the galactose residue (the first sugar in the $\mathrm{O}$ antigen repeat unit) to the LPS core. This permits the completion of the $\mathrm{O}$-antigen side chain in the absence of the $r f p$ gene (present in the 6-Mda plasmid) which encodes the specific galactosyl transferase involved in $\mathrm{O}$-antigen biosynthesis. Thus, our findings indicate that the 6Mda plasmid of $S$. dysenteriae type 1 has an important role in the synthesis of the Oantigen side chains of LPS. However, the 140-, 4- and 2-Mda plasmids may also be indirectly responsible for these properties, but this may be less pronounced in the absence of the 6-Mda plasmid.
\end{abstract}

\section{Introduction}

Recently we reported ${ }^{1}$ the presence of four plasmids $(140,6,4$, and $2 \mathrm{Mda})$, in a significant number of Shigella dysenteriae type 1 strains from widely scattered geographic locations. Our findings indicated that these plasmids may play a role in certain virulence-associated characters in this serotype of Shigella. We isolated mutant strains that contained only one of the four plasmids.

Recently, there has been considerable interest in the role of plasmids in the biological properties of shigellae. Until 1980, no plasmids, other than resistance plasmids, were thought to play any role

Received 22 Nov. 1989; accepted 12 Feb. 1990. in the virulence of dysentery bacilli. Studies over the past 8 years have demonstrated that the ability of shigellae ${ }^{2-4}$ and enteroinvasive Escherichia coli (EIEC) $^{5}$ to invade epithelial cells is plasmidmediated. Hale et al. ${ }^{6}$ demonstrated that synthesis of outer-membrane proteins was plasmid-mediated. Seven of these proteins appeared to be associated with the virulent phenotype in both $S$. flexneri and EIEC. Recent studies have shown that plasmids may also be involved in expression of lipopolysaccharide (LPS) in Salmonella and in E. coli. ${ }^{8}$ Similarly, the expression of LPS has been shown to be mediated by plasmids in several Shigella spp. ${ }^{9,10}$ and by chromosomal genes in others. ${ }^{10,11}$

In this study we report the association between the presence of four plasmids in $S$. dysenteriae type 
1 strains and (1) the expression of particular virulence characters-agglutination, colony morphology, Congo red binding, production of outermembrane protein (OMP), toxin production, presence of virulence marker antigen, invasivenessand (2) LPS expression.

\section{Materials and methods}

\section{Bacterial strains}

Two virulent and seven avirulent strains of $S$. dysenteriae type 1 were used in the study (table). The virulent strains were isolated from patients at the ICDDR, B, Dhaka treatment centre. The avirulent strains were derived from the virulent strains by repeated subculturing (approximately seven times) on MacConkey Agar (Difco). Loss of virulence was confirmed by the Congo red binding assay, the Sereny test, and HeLa-cell infectivity as described below. The roughness of the avirulent mutants was ascertained by autoagglutination in physiological saline. Non-pathogenic E. coli strain C600 was obtained from the Centers for Disease Control (Atlanta, GA, USA) and enteroinvasive E. coli strain BH-16-1 was from the Armed Forces Research Institute of Medical Services, Bangkok, Thailand. All these strains were stored at $-70^{\circ} \mathrm{C}$ in Trypticase Soy Broth (TSB; Gibco), with glycerine $15 \%$.

Strains were subcultured on Trypticase Soy Agar (TSA) and MacConkey Agar and were identified serologically by slide agglutination tests with $S$. dysenteriae type 1 antiserum (Wellcome). ${ }^{12}$

\section{Congo red binding assay and salt aggregation test}

Strains were streaked on TSA with Yeast Extract (Gibco) $0.6 \%$ containing Congo red (Fisher Scientific Co., NJ, USA) $0.003 \%$. Plates were incubated at $37^{\circ} \mathrm{C}$ for $18 \mathrm{~h}$ to differentiate between pigmented $\left(\mathrm{Pcr}^{+}\right)$and non-pigmented $\left(\mathrm{Pcr}^{-}\right)$colonies as described previously. ${ }^{13,14}$ The salt aggregation test (SAT) for hydropho- bicity was performed with growth taken from TSA $;^{14}$ aggregation was determined in ammonium sulphate solutions of various molarity.

\section{Sereny test}

For Sereny's test of virulence, $20 \mu \mathrm{l}$ of a suspension of $S$. dysenteriae type 1 containing $3 \times 10^{8} \mathrm{cfu} / \mathrm{ml}$ was inoculated into the eye of adult guinea pigs. ${ }^{15}$ Strains that produced keratoconjunctivitis within $72 \mathrm{~h}$ were considered to be virulent.

\section{Invasion of HeLa cells}

Broth cultures $(18 \mathrm{~h})$ of all strains, adjusted to a concentration of $2 \times 10^{8} \mathrm{cfu} / \mathrm{ml}$, were used to infect nonconfluent $\mathrm{HeLa}$ cell monolayers for determination of invasive ability by the method of Hale et al. ${ }^{16}$

\section{Analysis of plasmid DNA}

Plasmid DNA was extracted from the strains by a modification of the method of Birnboim and Doly. ${ }^{17}$ The plasmids were separated by electrophoresis for $2 \mathrm{~h}$ at $30 \mathrm{~mA}$ in agarose $0.7 \% .{ }^{18}$ Preparations of plasmid DNA from each virulent $S$. dysenteriae type 1 strain were electrophoresed, either singly or mixed with DNA from its avirulent isogenic pair to detect the deletion in the large (140 Mda) plasmid, for $4 \mathrm{~h}$ at $30 \mathrm{~mA}$ in agarose $0.7 \%$. Reference marker plasmids of pDK-9 (140, 105, $2 \cdot 7$, and $2 \cdot 0 \mathrm{Mda}$ ), R1 (62 Mda), RP4 (36 Mda) and Sa (23 Mda) were used to determine the $\mathrm{M}_{\mathrm{r}}$ of the plasmid DNA of $S$. dysenteriae type 1 strains.

\section{Modified ELISA for detecting virulent Shigella strains}

Virulence marker antigen (VMA) was detected by the ELISA method as modified by Pal et al. ${ }^{19}$ Virulent and avirulent strains were distinguished by tests with an absorbed immune serum that contained ELISA-reactive

Table. Plasmid content and virulence characters of $S$. dysenteriae type 1 strains

\begin{tabular}{|c|c|c|c|c|c|c|c|}
\hline Strain no. & $\begin{array}{l}\text { Plasmid profile } \\
\text { (Mda) }\end{array}$ & $\begin{array}{c}\text { Colony } \\
\text { morphology }\end{array}$ & $\begin{array}{l}\text { SAT } \\
\text { value }\end{array}$ & $\begin{array}{l}\text { Congo red } \\
\text { binding }\end{array}$ & $\begin{array}{l}\text { Sereny } \\
\text { test }\end{array}$ & $\begin{array}{c}\text { VMA } \\
\text { production }\end{array}$ & $\begin{array}{l}\text { Shiga } \\
\text { toxin }\end{array}$ \\
\hline Z-24623 & $140,6,4,2$ & Smooth & $1 \cdot 5$ & + & + & + & + \\
\hline Z-24623-1 & $128,6,4,2$ & Smooth & $1 \cdot 5$ & - & - & - & + \\
\hline$Z-26406$ & $140,6,4,2$ & Smooth & $1 \cdot 5$ & + & + & + & + \\
\hline $\bar{Z}-26406-1$ & $128,6,4,2$ & Smooth & $1 \cdot 5$ & - & - & - & + \\
\hline PSD-1 & 2 & Semi-rough & 0.25 & + & - & - & + \\
\hline PSD-10 & 4,20 & Semi-rough & aa & + & - & - & + \\
\hline PSD-20 & 6 & Smooth & $1 \cdot 0$ & - & - & - & + \\
\hline PSD- -30 & 140,90 & Semi-rough & aa & + & - & - & + \\
\hline PSD -40 & 90 & Rough & aa & + & - & - & + \\
\hline
\end{tabular}

aa, Autoagglutination in physiological saline, i.e., rough strain. 
antibodies specific for a possibly unique antigen site (VMA) of the virulent strains.

\section{Toxin assay}

Overnight bacterial growth on heart-infusion agar slopes was washed with $1 \mathrm{ml}$ of polymyxin B sulphate (Sigma) $1 \mathrm{mg} / \mathrm{ml}$ in $0.01 \mathrm{M}$ phosphate-buffered saline, incubated for $15 \mathrm{~min}$ at $37^{\circ} \mathrm{C}$ and centrifuged in a microfuge for $10 \mathrm{~min}$. The supernates were diluted 1 in 10 and 1 in 100 in cell-culture media and $0.1 \mathrm{ml}$ amounts of the dilutions were inoculated into the wells of a microtitration plate containing a $24-\mathrm{h}$ culture of HeLa cells. ${ }^{20}$ The treated cell cultures were incubated overnight and examined microscopically for cell death, indicative of toxin production by the Shigella strain.

\section{Outer-membrane protein (OMP) extraction}

Shigella strains were grown in $100 \mathrm{ml}$ of TSB containing yeast extract $0 \cdot 3 \%$ at $37^{\circ} \mathrm{C}$ for $18 \mathrm{~h}$. After centrifugation, the bacterial pellets were suspended in $80 \mathrm{ml}$ of deionised water and incubated at room temperature for $1 \mathrm{~h}$ with slow shaking ( $60 \mathrm{rpm}$ on a rotary shaker) according to the method described previously. ${ }^{21}$ After removal of bacterial cells by centrifugation at $16000 \mathrm{~g}$ for $20 \mathrm{~min}$, the supernate was again centrifuged at $100000 \mathrm{~g}$ for $2 \mathrm{~h}$. The clear supernate was dialysed against buffer, concentrated by dialysis against polyethylene glycol (PEG $15000-20000$ ) and stored at $-20^{\circ} \mathrm{C}$.

\section{Sodium dodecyl sulphate-polyacrylamide gel electrophoresis (SDS-PAGE) of OMPS}

Isolated OMPs were analysed by SDS-PAGE ${ }^{22}$ with separating gels containing acrylamide $13.5 \%$ and stacking gels containing acrylamide $5 \%$, and with electrophoresis at a constant current of $10 \mathrm{~mA}$ per gel overnight. Gels were stained with Coomassie Brilliant Blue $\mathrm{R}-2500 \cdot 2 \%$ for the demonstration of proteins.

\section{Extraction and analysis of LPS}

LPS was extracted from the strains by a modified phenol-water extraction procedure ${ }^{23}$ and purified by ultracentrifugation at $105000 \mathrm{~g}$ for $4 \mathrm{~h}$. Purified preparations of LPS were analysed by SDS-PAGE in polyacrylamide $12 \%$ gels. ${ }^{22}$ LPS components separated in the gel were visualised by the silver staining technique of Hitchcock and Brown. ${ }^{24}$

\section{Preparation of antiserum}

$S$. dysenteriae type 1 strain $\mathrm{Z}-24623$ was grown in $100 \mathrm{ml}$ of TSB for $18 \mathrm{~h}$ at $37^{\circ} \mathrm{C}$. The bacterial cells were harvested by centrifugation at $8000 \mathrm{~g}$, washed in PBS

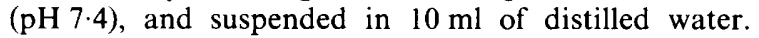
Whole-cell extracts were prepared by shaking the pellets with glass beads at high speed, on a rotary shaker, for $1 \mathrm{~h}$ at room temperature. The suspension was then sonicated for three 1-min bursts, at intervals of $30 \mathrm{~s}$, in an ultrasonic disintegrator (Fisher Sonic Dismembrator, Model 300, Fairlawn, NJ, USA). Two adult albino rabbits of $2 \mathrm{~kg}$ average weight were immunised with the preparation. The first dose, equivalent to $10^{6}$ cells, was given intravenously; after 1 week, four doses $\left(10^{7}, 5 \times 10^{7}, 10^{8}\right.$, and $5 \times 10^{8}$ cells) were given at 2-day intervals and a last dose of $10^{9}$ cells was given after another 1 -week gap. The titre of the sera was determined and a further booster injection was given if required. Serum was collected one week after the last dose, pooled, divided into $1-\mathrm{ml}$ volumes and stored at $-20^{\circ} \mathrm{C}$.

\section{Immunoblotting}

OMPs and LPS, after separation on SDS-polyacrylamide gels, were separately transferred to nitrocellulose membranes. ${ }^{25}$ The polyclonal antisera, raised in rabbits against whole-cell extracts of the $S$. dysenteriae type 1 strain, were diluted 1 in 500 and incubated, separately, with OMPs and LPS on the nitrocellulose sheet for $2 \mathrm{~h}$ at $37^{\circ} \mathrm{C}$. OMP and LPS antigens were detected with anti-S. dysenteriae type $1(\mathrm{Z}-24623)$ rabbit serum. Swine antirabbit immunoglobulin conjugated to alkaline phosphatase (Dakopatts, Denmark) was used as secondary antibody. Alkaline phosphatase activity was detected with napthol AS-MX phosphate $(2 \mathrm{~g} / \mathrm{L})$ and Fast Red TR Salt (Sigma) $(1 \mathrm{~g} / \mathrm{L})$ in $50 \mathrm{~mm}$ Tris-HCl buffer, $\mathrm{pH} 8 \cdot 5$.

\section{Crossed immuno-electrophoresis}

Crossed immuno-electrophoresis was performed by the method of Kroll. ${ }^{26}$

\section{Results}

\section{Plasmid profile, colony morphology and SAT values}

The virulence characters of the strains are summarised in the table. The two virulent strains (Z-24623 and $\mathrm{Z}-26406$ ) each contained four plasmids of $140,6,4$, and $2 \mathrm{Mda}$ (fig. 1). Their avirulent isogenic pairs each had a small deletion of $c .12-$ Mda from the 140-Mda plasmid (fig. 2). Strains containing either all four plasmids or the 6-Mda plasmid alone (PSD-20) were smooth in physical appearance, did not autoagglutinate in physiological saline, and had SAT values of 1.0 or $1.5 \mathrm{M}$. Strains without the 6-Mda plasmid were either semi-rough (PSD-1, 10, 30) or completely rough (PSD-40) in appearance and either autoagglutinated in physiological saline or showed greater hydrophobicity (SAT value $0.25 \mathrm{M}$ for strain PSD1).

\section{Congo red binding and virulence characters}

Smooth strains, possessing all plasmids, bound Congo red and produced distinct red colonies after 


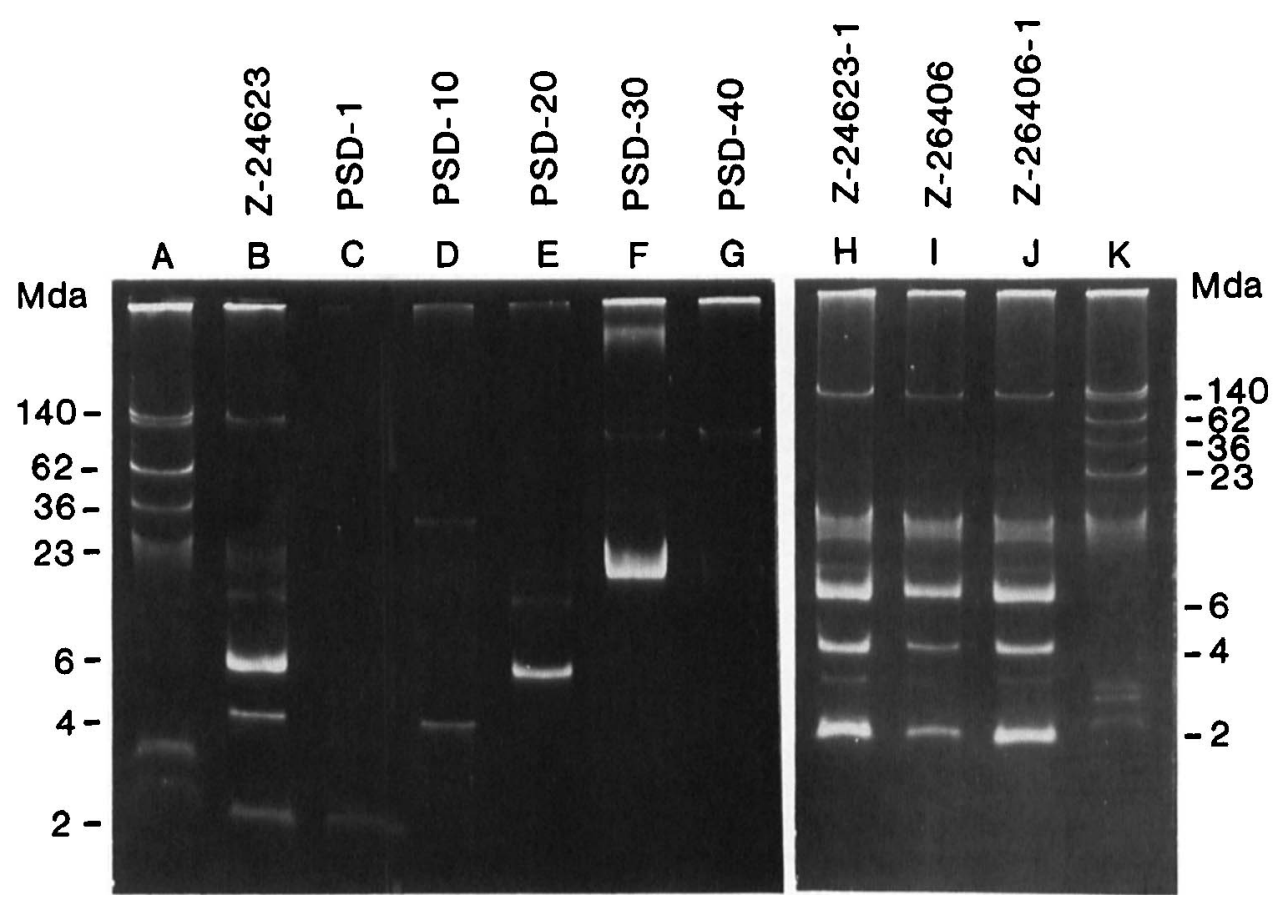

Fig. 1. Plasmid DNA patterns of $S$. dysenteriae type 1 strains electrophoresed for $2 \mathrm{~h}$ at $30 \mathrm{~mA}$ in agarose $0.7 \%$ gel: lanes $\mathbf{A}$ and $\mathbf{K}$ contain marker plasmids: B, virulent strain $Z-24623 ; \mathbf{C}-\mathbf{G}$, avirulent mutant strains; H, avirulent strain $Z-24623-1$; I, virulent strain Z-26406; J, a virulent strain Z-26406-1.

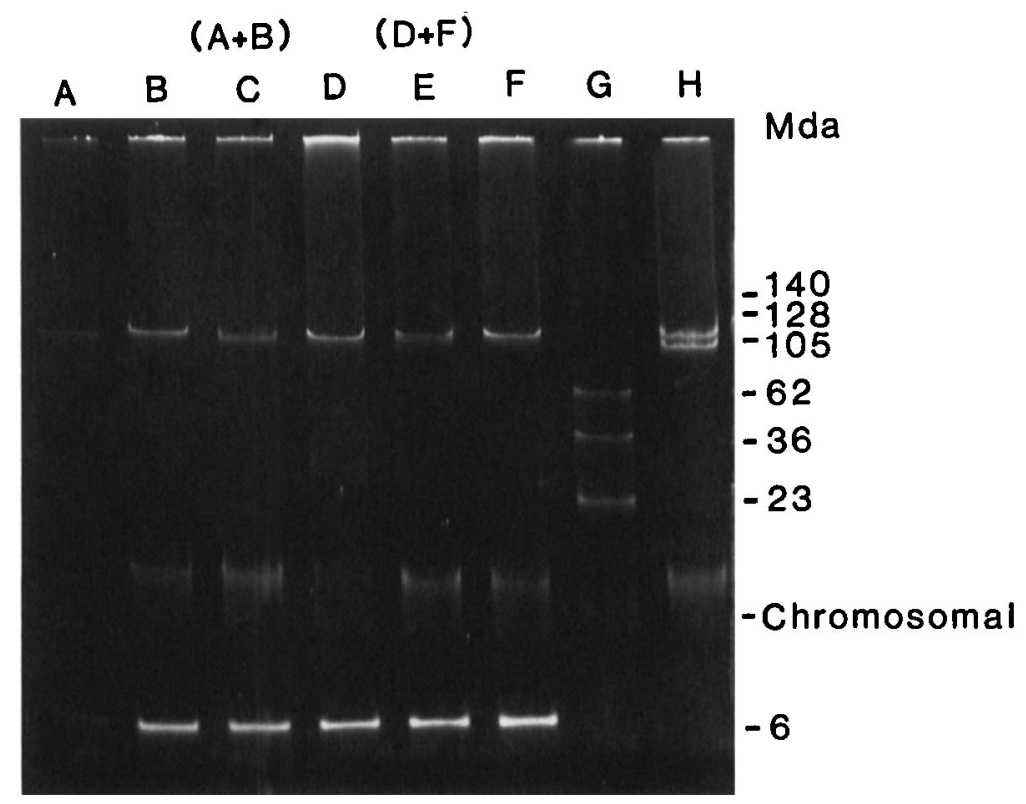

Fig. 2. Electrophoretic patterns of plasmid DNA from virulent and avirulent isogenic pairs of $S$. dysenteriae type 1 strains electrophoresed for $4 \mathrm{~h}$ at $30 \mathrm{~mA}$ in agarose $0.7 \%$ gel: lanes $A$ and $D$, avirulent strains $Z-24623-1$ and $Z-26406-1$, respectively; B and F, virulent strains Z-24623 and Z-26406; C, plasmid DNA from strains Z-24623 and Z-24623-1: E, plasmid DNA from strains Z-26406 and Z-26406-1 ; G, marker plasmids R1, Sa, RP4; H, marker plasmid pDK-9. 
growth on Congo red agar. However, smooth strains with partial or complete deletion of the 140Mda plasmid had distinct white colonies. Rough strains with or without the 140 -Mda plasmid also bound Congo red. Only the smooth red colonies contained the VMA, gave positive results in Sereny's test of virulence and were invasive for HeLa cells; the smooth white colonies and rough red colonies gave negative results in both tests. All strains, whether they were smooth or rough, red or white, Sereny positive or negative, produced Shiga toxin.

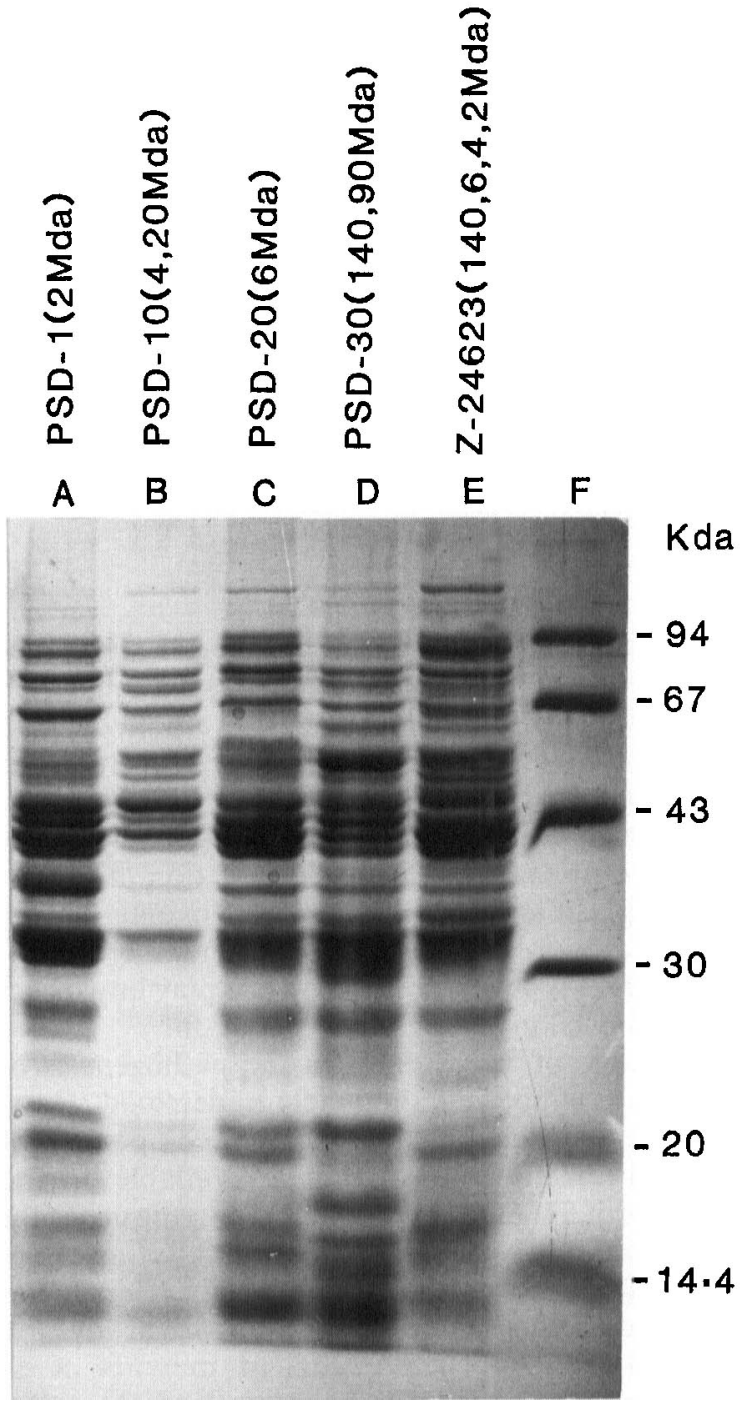

Fig. 3. OMPs extracted from avirulent strains of $S$. dysenteriae type 1 (lanes A-D) and from a virulent strain (lane E) separated by SDS-PAGE in a $13.5 \%$ gel and stained with Coomassie Brilliant Blue. Polypeptides are present in almost equal quantities in all strains except PSD-10 (lane B). Marker proteins are shown in lane $\mathbf{F}$.

\section{Analysis of $O M P$ s}

SDS-PAGE of OMPs showed the presence of several $(\simeq 30)$ polypeptides of $10->100 \mathrm{Kda}$ (fig. 3). The OMP profile of strain PSD-10 that lacked the "core plasmids", ${ }^{1}$ i.e., those of 140,6 and $2 \mathrm{Mda}$, showed both qualitative and quantitative differences (fig. 3; lane B) from the virulent parent strain. Other mutants did not show such a clear difference. No change in the antigenic profile was observed (fig. 4) as a result of the small deletion of the 12-Mda segment from the 140-Mda plasmid or complete deletion of the 140-Mda plasmid, although there was a change in their virulence properties.

\section{Analysis of LPS}

SDS-PAGE of LPS showed O-side chain repeat units. These were present in all smooth strains that contained the 6-Mda plasmid (fig. 5; lanes A and B). However, smaller numbers of regularly spaced LPS bands were also observed (fig. 5; lanes C-E) in strains that did not contain the 6-Mda plasmid. These strains contained the 2-, 4- or 140-Mda plasmid. In contrast, in the rough strain PSD-40, which contained none of the four plasmids, only

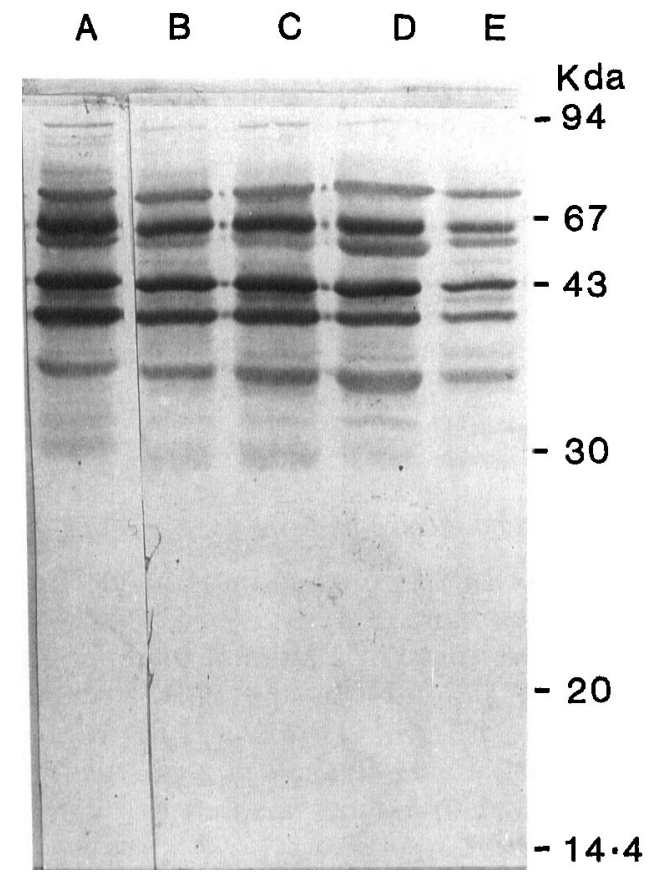

Fig. 4. Immunoblot analysis of OMPs extracted from avirulent strains PSD-1 (A), 10 (B), 20 (C) and 30 (D) and from the virulent $S$. dysenteriae type 1 strain $Z-24623$ (E). The OMPs were transferred to nitrocellulose and detected with a polyclonal rabbit antiserum raised against strain Z,-24623. 


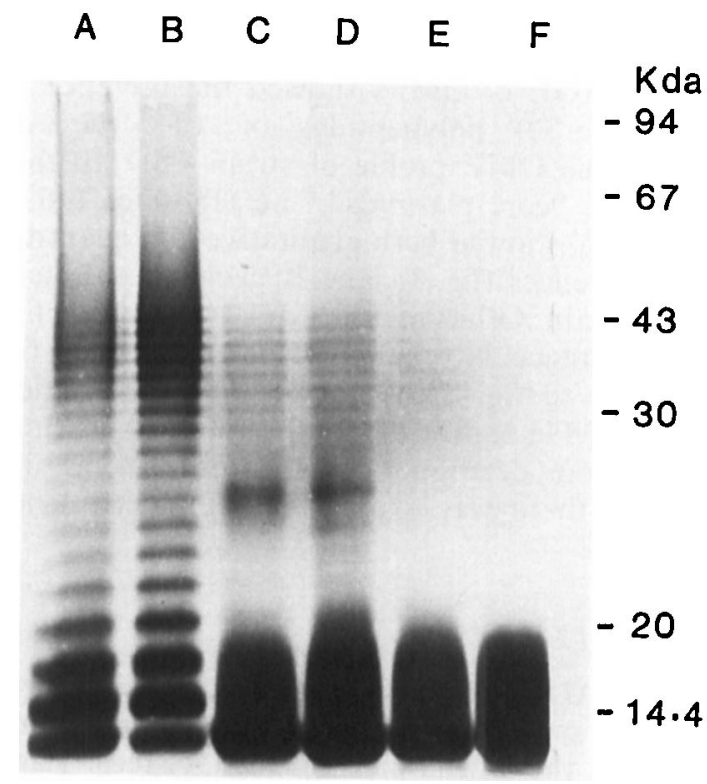

Fig. 5. SDS-PAGE of LPS from $S$. dysenteriae type 1 strains carrying different plasmids. LPS bands were visualised by staining with silver stain (Bio-Rad). Lanes $\mathbf{A}$ and $\mathbf{B}$, complete synthesis of LPS by strains Z-24623 and PSD-20; C-E, reduced quantities of O-repeat unit of LPS in strains PSD-30, PSD-10 and PSD-1, respectively; F, PSD-40 showing presence of core polysaccharide but absence of $\mathrm{O}$-side chains.

core polysaccharide without any $\mathrm{O}$-side chain repeat units was detected (fig. 5; lane F).

In Western blots, a characteristic pattern of complete O-side chain of LPS was recognised by rabbit anti-S. dysenteriae $\mathrm{Z}-24623$ sera in strains containing the 6-Mda plasmid (fig. 6). However, strains PSD-1, PSD-10 and PSD-30 showed Oside chain repeat units but in much reduced amount. None of these oligosaccharide bands was observed in strain PSD-40 (fig. 6).

\section{Crossed immuno-electrophoresis}

Analysis of LPS by crossed immuno-electrophoresis with rabbit anti-S. dysenteriae $\mathrm{Z}-24623$ serum showed the presence of a band of low mobility in strains Z-24623, Z-24606 and PSD-20 which is characteristic of LPS. ${ }^{27}$ However, LPS from other strains, except PSD-40, showed a relatively faint precipitin band. No band was detected with LPS from PSD-40.

\section{Discussion}

Genetic analysis of Shigella spp. has shown that plasmids, ${ }^{3,9}$ as well as chromosomal loci, ${ }^{10,11}$ play

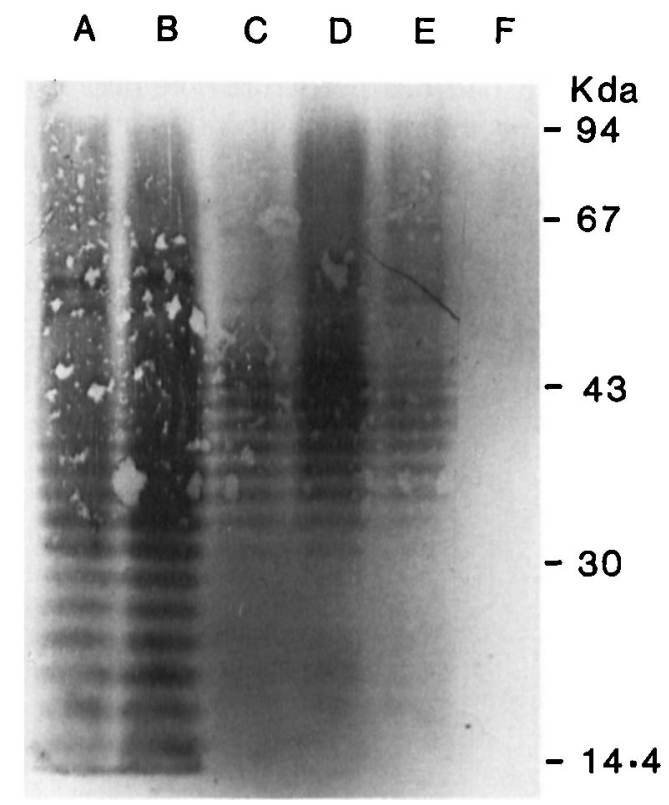

Fig. 6. Immunoblot analysis of LPS from strains Z-24623 (A), PSD-20 (B), PSD-30 (C), PSD-10 (D), PSD-1 (E) and PSD-40 (F). LPS bands were determined by electroblotting to nitrocellulose and detected with a polyclonal antiserum raised against strain Z-24623.

an important role in virulence properties. Evidence gathered over the past few years has demonstrated that large plasmids of $120-140 \mathrm{Mda}$ are involved in the invasive process ${ }^{4}$ in all shigellae. Our study has indicated that a small segment of the 140-Mda plasmid in $S$. dysenteriae type 1 is involved in the invasive process and in the production of VMA. Other plasmids, i.e., those of 6,4 , and $2 \mathrm{Mda}$, which are present in significant numbers of $S$. dysenteriae type 1 strains $^{1}$ may not play any direct role in invasion or in VMA production.

The role of Shiga toxin in the pathogenesis of dysentery is not yet completely understood. However, it is probably an essential component of virulence. Little information is available on the genetics of Shiga toxin production but the genes for this toxin in $S$.dysenteriae type 1 and the Shiga-like toxin of $S$. flexneri appear to be located on the chromosome. The production of toxin by the plasmid-less or plasmid-deficient mutants of $S$. dysenteriae type 1 in our study also indicates that plasmids might not have any direct role in toxin production.

Previous studies in this laboratory have shown that Congo red binding may reflect an arrangement of cell-surface components. ${ }^{14}$ The presence of the 
O-side chain of LPS is essential if the Congo red binding assay is to be used as an indicator of virulence. To understand the contribution of the $\mathrm{O}$ side chain of LPS to Congo red binding, we have compared the binding ability of avirulent rough mutants of $S$. dysenteriae type 1 with that of the avirulent smooth strains, in both cases with or without the 140-Mda plasmid. We have found that the rough strains, with or without the $140-\mathrm{Mda}$ plasmid, do bind Congo red whereas the smooth strains do not. Experiments also indicated that the $\mathrm{O}$-side chains represent an important factor determining hydrophobicity of the cell, as indicated by the SAT. ${ }^{14}$ This was substantiated by the observation that rough mutants lacking antigens had much greater hydrophobicity than the equivalent smooth strain and were auto-agglutinating. The genetic locus encoding $\mathrm{Pcr}^{+}$phenotype has been cloned and expressed in $E$. coli and has been found to be present in the 140-Mda plasmid. ${ }^{28,29}$ Absence of O-antigen may cause more exposure of outermembrane and thus, probably, make the rough strains more hydrophobic and allow binding to Congo red. The role of $\mathrm{O}$-antigen in virulence is not fully understood, but smooth LPS may be important both for intra-luminal survival of shigellae and for protection of the bacteria in tissue from the bactericidal activity of serum.

We have found a significant difference between the OMP profile of one of the rough mutants (PSD10 , containing 4- and 20 -Mda plasmids) and that of the parent strain. Some minor differences of the other OMPs obtained from the three rough mutants of $S$. dysenteriae type 1 were also seen, although the major polypeptides were similar. Analysis of the OMPs by Western blotting showed that the avirulent mutants, either rough or smooth strains, did not have decrease antigenicity.

OMPs in strains of $S$. flexneri, S. sonnei and $E$. coli $^{6}$ have been shown to influence virulence properties. The loss of major polypeptides led to loss of the invasive potential of the bacteria. However, the results obtained with mutants of $S$. dysenteriae type 1 , show that loss of virulence does not result in loss of antigenicity of the OMPs. It is possible that, in $S$. dysenteriae type 1, the gene essential for the invasive process and VMA production may not be essential for the synthesis of the major polypeptides.

Plasmid-mediated synthesis of LPS in the Enterobacteriaceae has been described before. ${ }^{8}$ The involvement of a small, 6-Mda plasmid in expression of LPS in $S$. dysenteriae type $1^{9}$ has been shown previously. We have demonstrated that, although the 6-Mda plasmid of $S$. dysenteriae type 1 is essential for the synthesis of intact LPS, other plasmids, i.e., those of 140,4 and $2 \mathrm{Mda}$, might have some role in the expression of LPS of this serotype. It has been shown that when the $r f b-r f p$ cassette is expressed in strains of Salmonella and $E$. coli, reduced levels of $\mathrm{O}$-antigen are expressed. ${ }^{30-32}$ The most likely explanation for this observation is that there are several housekeeping functions involved in galactose metabolism and some of these are shared (with relaxed specificity) not only for expression of $\mathrm{O}$-antigen but also for core biosynthesis. Similar functions can, nonspecifically and at a reduced level, add the galactose residue to the LPS core. This permits the completion of the O-antigen side chain in the absence of the $r f p$ gene which encodes the specific galactosyl-transferase involved in $\mathrm{O}$-antigen biosynthesis. Therefore, on the basis of previously published information ${ }^{30-}$

32 and our data, the 140-, 4- and 2-Mda plasmids most likely encode a non-specific galactosyl transferase-like activity when the gene for $\mathrm{O}$-antigen biosynthesis is absent, i.e., the 6-Mda plasmid or the $r f p$ gene. The 6-, 4- and 2-Mda plasmids are unique in $S$. dysenteriae type 1 and are not breakdown products of the 140 -Mda plasmid. ${ }^{1}$

In our study we did not determine how these plasmid-encoded factors are involved in $\mathrm{O}$-side chain expression. It has been demonstrated that chromosomal determinants are important for LPS expression. However, the complex mechanism regulating assembly of LPS in the outer membrane may be under the influence of plasmid-determined factors. Watanabe and Timmis ${ }^{9}$ demonstrated that a small, 6-Mda plasmid in $S$. dysenteriae type 1 is involved in expression of somatic antigen, although other chromosomal factors may be needed as well.

Diminished reactivity of rabbit anti-S. dysenteriae Z-24623 sera with the LPS from strains containing the 140-, 4- or 2-Mda plasmid was seen and this may be caused by the decrease in the number of $\mathrm{O}$-side chains per core. Other factors may be involved as well and this deserves further investigation.

From our study, it appears that the 140-, 4- and 2-Mda plasmids of $S$. dysenteriae type 1 strains also may have some involvement in the synthesis of the $\mathrm{O}$-antigen. The strains may be deficient in the gene coding for an enzyme responsible for adding the first sugar of the O-antigen repeat unit to the LPS core. It is also possible that genes may encode factors that regulate chromosomal determinants of the LPS. However, detailed biochemical and genetic studies are required to understand the mechanisms.

As observed by other investigators, ${ }^{2-5,9}$ we also 
feel that the 6- and 140-Mda plasmids are most important for the virulence potential of $S$. dysenteriae type 1 strains. However, other plasmids, such as those of 4 and 2 Mda, may also have an important role to play in the pathogenicity of this serotype although the effect may be less pronounced.

\section{REFERENCES}

1. Haider K, Kay BA, Talukder KA, Huq MI. Plasmid analysis of Shigella dysenteriae type 1 isolates obtained from widely scattered geographical locations. $J$ Clin Microbiol 1988; 26: 2083-2086.

2. Sansonetti PJ, Kopecko DJ, Formal SB. Shigella sonnei plasmids: evidence that a large plasmid is necessary for virulence. Infect Immun 1981; 34: 75-83.

3. Sansonetti PJ, Kopecko DJ, Formal SB. Involvement of a plasmid in the invasive ability of Shigella flexneri. Infect Immun 1982; 35: 852-860.

4. Silva RM, Toledo MRF, Trabulsi LR. Plasmid-mediated virulence in Shigella species. J Infect Dis 1982; 146: 99.

5. Sansonetti PJ, D'Hauteville H, Formal SB, Toucas M. Plasmid mediated invasiveness in "Shigella-like" Escherichia coli. Ann Microbiol (Paris) 1982; 132: 351-355.

6. Hale TL, Oaks EV, Formal SB. Identification and antigenic characterization of virulence-associated plasmidcoated proteins of Shigella species and enteroinvasive Escherichia coli. Infect Immun 1985; 50: 620-629.

7. Popoff MY, LeMinor L. Expression of antigenic factor $0: 54$ is associated with the presence of a plasmid in Salmonella. Ann Inst Pasteur Microbiol 1985 ; 136b: 169179.

8. Riley LW, Junio LN, Libaek LB, Schoolnik GK. Plasmidencoded expression of lipopolysaccharide $\mathrm{O}$-antigenic polysaccharides in enteropathogenic Escherichia coli. Infect Immun 1987; 55: 2052-2056.

9. Watanabe H, Timmis KN. A small plasmid in Shigella dysenteriae 1 specifies one or more functions essential for $\mathrm{O}$-antigen production and bacterial virulence. Infect Immun 1984; 43: 391-396.

10. Sansonetti PJ, Hale TL, Dammin GJ, Kapfer C, Collins $\mathrm{HH}$, Formal SB. Alterations in the pathogenicity of Escherichia coli $\mathrm{K} 12$ after transfer of plasmid and chromosomal genes from Shigella flexneri. Infect Immun 1983; 39: 1392-1402.

11. Hale TL, Guerry P, Seid SC et al. Expression of lipopolysaccharide $\mathrm{O}$-antigen in Escherichia coli $\mathrm{K} 12$ hybrids containing plasmid and chromosomal genes from Shigella dysenteriae 1. Infect Immun 1984; 46: 470-475.

12. Ewing WH, Lindberg AA. Serology of Shigella. In : Bergan $\mathrm{T}$ (ed) Methods in microbiology. London, Academic Press. 1984; 14: 113-142.

13. Maurelli AT, Blackmon B, Curtiss R. Loss of pigmentation in Shigella flexneri 2a correlated with loss of virulence and virulence associated plasmid. Infect Immun 1984; 43: $397-401$.

14. Qadri F, Hossain SA, Ciznar I et al. Congo red binding and salt aggregation as indicator of virulence in Shigella species. J Clin Microbiol 1988; 26: 1343-1348.

15. Sereny B. Experimental Shigella keratoconjunctivitis. Acta Microbiol Acad Sci Hung 1955; 2 : 293-296.

16. Hale TL, Formal SB. Protein synthesis in HeLa or Henle
This work was supported by the International Centre for Diarrhoeal Disease Research, Bangladesh (ICDDR,B) which is supported by grants from the United States Agency for International Development, the United Nations Development Project, the Government of Japan, the Swedish Agency for Research, and the World Health Organization. We thank Manzurul Haque of the ICDDR,B for his secretarial assistance.
407 cells infected with Shigella dysenteriae 1, Shigella flexneri $2 \mathrm{a}$ or Salmonella typhimurium W118. Infect Immun $1981 ; 32$ : 137-144.

17. Birnboim HC, Doly J. A rapid alkaline extraction procedure for screening recombinant plasmid DNA. Nucl Acid Res 1979; 7: 1513-1523.

18. Meyers JA, Sanchez D, Elwell LP, Falkow S. Simple agarose gel electrophoretic method for the identification and characterization of plasmid deoxyribonucleic acid. $J$ Bacteriol 1976; 127: 1529-1537.

19. Pal T, Pacsa AS, Emody L, Voros S, Selley E. Modified enzyme-linked immunosorbent assay for detecting enteroinvasive Escherichia coli and virulent Shigella strains. J Clin Microbiol 1985; 21 : 415-418.

20. Gentry MK, Dalrymple JM. Quantitative microtiter cytotoxicity assay for Shigella toxin. J Clin Microbiol 1980; 12: $361-366$.

21. Oaks EV, Hale TL, Formal SB. Serum immune response to Shigella protein antigens in Rhesus monkeys and humans infected with Shigella spp. Infect Immun 1986; 53: $57-63$.

22. Laemmli UK. Cleavage of structural proteins during the assembly of the head of bacteriophage T4. Nature 1970; 227: 680-685

23. Westphal O, Jahn K. Bacterial lipopolysaccharide. Extraction with phenol water and further application of the procedure. Methods Carbohydr Chem 1965; 5: 83-91.

24. Hitchcock PJ, Brown TM. Morphological heterogeneity among Salmonella lipopolysaccharide chemotypes in silver-stained polyacrylamide gels. J Bacteriol 1983; 154: $269-277$.

25. Towbin H, Staehelin T, Gordon J. Electrophoretic transfer of protein from polyacrylamide gels to nitrocellulose sheets: procedures and some applications. Proc Natl Acad Sci USA 1979; 76, 4350-4354.

26. Kroll J. Crossed-line immunoelectrophoresis. In: Axelsen NH, Kroll J, Weoke B (eds) A manual of quantitative immunoelectrophoresis. (Scand J Immunol, Suppl 1) Blackwell Scientific Publications. 1973: 79-81.

27. Qadri F, Raqib R, Husan IA, Ciznar I. Cell surface proteins from $S$. dysenteriae type 1. Zentralbl Bakteriol Mikrobiol $H y g$ [ $A]$ (In press).

28. Sasakawa C, Kamata K, Sakai T, Murayama SY, Makino S, Yoshikawa M. Molecular alteration of the 140Megadalton plasmid associated with loss of virulence and Congo red binding activity in Shigella flexneri. Infect Immun 1986; 51 : 470-475.

29. Sakai T, Sasakawa C, Makino S, Kamata K, Yoshikawa M. Molecular cloning of a genetic determinant for Congo red binding ability which is essential for the virulence of Shigella flexneri. Infect Immun 1986; 51 : 476-82.

30. Sturm S, Timmis KN. Cloning of the $\mathrm{rfb}$ gene region of Shigella dysenteriae 1 and construction of an $\mathrm{rfb}-\mathrm{rfp}$ 
gene cassette for the development of lipopolysaccharide-based live anti-dysentery vaccines. Microb Pathog 1986; 1: 289-297.

31. Sturm S, Jann B, Jann K, Fortnagel P, Timmis KN. Genetic and biochemical analysis of Shigella dysenteriae $1 \mathrm{O}-$ antigen polysaccharide biosynthesis in Escherichia coli $\mathrm{K}-12: 9 \mathrm{~kb}$ plasmid of $S$. dysenteriae 1 determines addition of a galactose residue to the lipopolysaccharide core. Microb Pathog 1986; 1 : 299-306.

32. Sturm S, Jann B, Jann K, Fortnagel P, Timmis KN. Genetic and biochemical analysis of Shigella dysenteriae $1 \mathrm{O}$ antigen polysaccharide biosynthesis in Escherichia coli K12 structure and functions of the $\mathrm{rfb}$ gene cluster. Microb Pathog 1986; 1 : 307-324. 